\title{
Study of the role of exhaled nitric oxide (NO) in predicting controlled or uncontrolled asthma in asthmatic children
}

\author{
Xuan Ngo-Minh, ${ }^{1}$ Tram Tang-Thi-Thao, ${ }^{2}$ Nhu Doan-Thi-Quynh, ${ }^{2}$ Timothy J. Craig, ${ }^{3}$ Sy Duong-Quy ${ }^{1,2,3}$ \\ ${ }^{\text {I}}$ Department of Medicine, Pham Ngoc Thach University, Ho Chi Minh city, Vietnam \\ ${ }^{2}$ Clinical Research Center, Lam Dong Medical College, Dalat city, Vietnam \\ ${ }^{3}$ Division of Immuno-Allergology, Hershey Medical Center, Penn State Medical College, Hershey, PA, USA
}

\begin{abstract}
Background: Exhaled nitric oxide (NO), especially fractional concentration of exhaled NO (FENO) has been used to predict the responsiveness of inhaled corticosteroid (ICS) in children with asthma. However, the use of exhaled NO for predicting asthma control in children is still controversial.

Methods: This was a perspective observational study. Asthmatic children who were naïve to inhaled corticosteroid (ICS) were included in the present study. The measurements of FENO and CANO (concentration of NO in the gas phase of the alveolar), spirometry, blood eosinophil counts (BEC), and total IgE levels were done for each asthmatic child. All study subjects started proper asthma treatment after the enrollment.

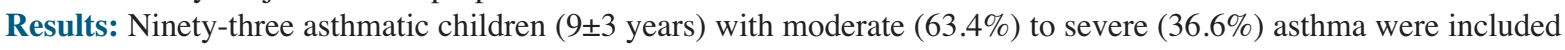
and finished the 3-month study. The levels of $F E N O$ and $C A N O$ at inclusion were $37 \pm 11 \mathrm{ppb}$ and $5.8 \pm 1.4 \mathrm{ppb}$, respectively; the mean of BEC was $617 \pm 258$ cells $/ \mu \mathrm{L}$; the level of total $\mathrm{IgE}$ was $1563 \pm 576 \mathrm{UI} / \mathrm{mL} ; 89 \%$ of subjects were positive for at least one respiratory allergen. The percentage of severe asthma was reduced significantly after 3 months $(\mathrm{P}<0.001)$. Well controlled asthma subjects at 3 months had higher levels of $F E N O$ and lower levels of $C A N O$ at inclusion $(\mathrm{P}<0.05$ and $\mathrm{P}<0.05)$. FENO $<20 \mathrm{ppb}$ or $C A N O>5 \mathrm{ppb}$ had a risk of uncontrolled asthma at 3 months $(\mathrm{OR}: 1.7, \mathrm{CI}$ 95\% [(0.8) - (3.3)], P<0.05; OR: 1.9, CI 95\% [(0.9) - (2.7)], P<0.05; respectively). FENO $>35$ ppb at inclusion had a positive predictive value for asthma control at 3 months (OR: 3.5, CI 95\% [2.2 - 5.9], P<0.01).

Conclusions: Exhaled NO is a biomarker of asthma which may have a potential role to predict the control of asthma in short-term follow-up in asthmatic children.
\end{abstract}

Key words: Asthma; asthma control; exhaled NO; FENO; CANO.

Correspondence: Pr. Sy Duong-Quy, Director of Clinical Research Center and Lam Dong Medical College, 16 Ngo Quyen, Dalat, Vietnam. Tel. +84.918413813 - Fax:+84.2633.815000. E-mail: sduongquy.jfvp@gmail.com

Contributions: XNM, TTTT, NDTQ, TJC, SDQ, work conception and design; XNM, TTTT, NDTQ, data acquisition, interpretation and analysis; XNM, NDTQ, TJC, SDQ, work drafting; XNM, TTTT, NDTQ, TJC, SDQ, review and editing. All authors approved the submitted version and agreed both to be personally accountable for the author's own contributions and to ensure that questions related to the accuracy and integrity of any part of the work, are appropriately investigated, resolved, and the resolution documented in the literature.

Conflict of interest: The authors declare no conflict of interest.

Funding: The study was supported by the Gant from Lam Dong Medical College (LDMC-SR.03.2018), Dalat city, Vietnam.

Availability of data and materials: The datasets used and/or analyzed during the current study are available from the corresponding author on reasonable request.

Ethics approval and consent to participate: The study was realized in accordance with the Declaration of Helsinki, and the protocol was approved by the Ethics Committee of Lam Dong Medical College Institutional Review Board. All study subjects had signed Informed Consent approved by Institutional Review Board (IRB) of Lam Dong Medical College.

Consent for publication: Not applicable. 
Multidisciplinary Respiratory Medicine 2020; 15:656 - X. Ngo-Minh et al.

\section{Introduction}

Asthma is a very common chronic respiratory disease in children [1]. It remains a leading cause of emergency department visits, hospitalization, and unscheduled school absences due to asthma exacerbations [2,3]. In Vietnam, the prevalence of school-age children with asthma has been varied from $5.1 \%$ up to $12.1 \%[4,5]$. Although many advancements have been discovered in the last decades over asthma management, obtaining well-controlled asthma in children is still a big challenge for physicians in practice. As with adults, the control of asthma in children is dependent mainly on their treatment responsiveness and adherence [1]. Moreover, it is challenging for pediatric physicians to predict the different levels of asthma control in short-term follow-up of their asthmatic patients. This problem has been due to the heterogeneity of asthma symptoms and phenotypes, especially in young children. Currently, the control of asthma has been measured by symptoms during the day and at night, during physical activities, and associated with the use of rescue treatment to relieve symptoms with short acting beta 2 agonist (SABA). However, in asthmatic children with moderate to severe asthma, the choice of predictive factors for asthma control remains an important issue for asthma management.

Currently, the use of GINA (Global Initiative for Asthma) recommendations for asthma control is often used in practice with three different control levels, including controlled (or totally controlled), partially controlled, and uncontrolled asthma [1]. In addition to GINA recommendations, the use of ACT (Asthma Control Test) and especially Childhood Asthma Control Test (cACT), useful for youngest children, have been equally available to evaluate the control of asthma [1,6]. In Vietnam, the local version of ACT for asthmatic children is also available for pediatric physicians and it has been considered as a useful additional tool for childhood asthma control $[7,8]$. According to that, different biomarkers have been studied and used to evaluate the level of asthma control in short-term follow-up such as blood or sputum eosinophil count, periostin, and exhaled nitric oxide (NO) [9-12]. In asthmatic adults, previous studies suggest that $F E N O$ (fractional concentration of exhaled NO) might be used to predict the persistence of asthma control in asymptomatic patients and can be used in asthma management [13-15]. Actually the association between FENO and current asthma control in adults is much more complex, with a clear correlation in patients who are naïve to ICS (inhaled corticosteroids) and very weak correlation when patients are properly treated; while FENO seems to be useful in predicting future risk of losing asthma control $[16,17]$. FENO can be measured by portable devices for evaluating the airway inflammation in asthmatic patients [18]. The use of exhaled NO for predicting asthma control in children is still controversial. However NICE guidelines recommend to consider FENO test in children and young people in case of uncertainty in the diagnosis (with a cut-off $35 \mathrm{ppb}$ ) [19].

In addition, the use of $\mathrm{NO}$ concentration in the gas phase of the alveolar (CANO) as an inflammatory biomarker of small airways in patients with asthma has been demonstrated [20-22]. It has been suggested that the increase of $C A N O$ level might reflect a severe or persistent asthma and the increase of CANO might reflect the allergic inflammation (Type 2 asthma) in distal airways [23,24]. Therefore, the present study aimed to clarify a predictive role of exhaled NO (FENO and CANO) in the control of asthma in children in short-term follow-up.

\section{Methods}

\section{Patients}

Asthmatic children who presented to the Clinical Research Center of Lamdong Medical College (Dalat, Vietnam) from June 2018 to June 2019 were eligible for the present study after their parents/guardians signed an Institutional Review Board-Approved consent form on the patient's behalf. This study was approved by the Ethic Council of Lamdong Medical College (04.18/LMCTTYSH-YD, approved in March 2018). The parents/guardians and patients also had been informed that they could withdraw of the study without the impact on asthma management.

\section{Inclusion criteria}

Asthmatic children over 6 years old who were newly diagnosed with asthma according to GINA [1] beginning of the study or who were previously diagnosed with asthma and did not take any daily treatment over one month were included in the present study. The included subjects were able to perform spirometry, exhaled NO measurements ( $F \mathrm{ENO}, C \mathrm{ANO}$ and $F \mathrm{nNO}$ [fractional concentration of nasally aspirated $\mathrm{NO}]$ ), blood tests, and skin prick test (SPT). Every subject had been followed and finished the study after three months.

\section{Exclusion criteria}

Patients who had one of the following criteria were excluded from the present study: being unable to perform spirometry or exhaled NO measurements; having other acute or chronic diseases such as congenital heart disease, hepatobiliary disorders, nephritic syndrome or chronic glomerulonephritis, acute respiratory infection, or psychological problems; being unable to obtain consent or absent during follow-up; having acute asthma exacerbations (AAE) at the beginning.

\section{Study design}

This was a prospective observational study. Patients with uncontrolled asthma who met the inclusion criteria were included and treated as recommended by GINA [1] and followed-up for three months. All the data concerning medical history, exposure to tobacco smoke, disease severity, laboratory tests including peripheral blood eosinophil counts (BEC), total IgE, skin prick test (SPT) with standard respiratory allergens, exhaled $\mathrm{NO}$ measurement ( $F \mathrm{ENO}, C \mathrm{ANO}$, and $\mathrm{nNO}$ ), and lung function testing were recorded for analysis.

The severity of asthma was defined by daytime symptoms, symptoms at night, asthma crisis, and airflow limitation measured by FEV1. Fluticasone propionate was used as ICS with moderate or high doses depending on asthma severity and combined with long acting beta agonist (LABA; salmeterol); short acting beta 2 agonist (SABA; albuterol) was used as a rescue treatment. All subjects had clinic visits after one month and three months for the assessment of asthma severity, asthma control by GINA and ACT (Asthma Control Test) in Vietnamese version for children of 4-11 years and $>11$ years, frequency of SABA use, lung function testing, and exhaled $\mathrm{NO}$ measurement ( $F \mathrm{ENO}, C \mathrm{ANO}$, and $F \mathrm{nNO}$ ). The adherent of asthmatic children was evaluated by the percentage of patients who did regularly their daily treatment during follow-up.

\section{Laboratory techniques}

Blood Eosinophil Count (BEC) and total IgE concentration quantifying. Blood samples of all study patients were collected through venipuncture and used for counting eosinophils and measuring total IgE. BEC in peripheral blood was analyzed by automat- 
ic machine. IgE concentration in peripheral blood was quantified by chemical luminescence technique (COBASC 501; Hitachi, Japan). The increases of eosinophil and total $\operatorname{IgE}$ in peripheral blood were defined by local Biology Lab (eosinophilils 6\%; total $\operatorname{IgE}>214 \mathrm{UI} / \mathrm{mL}$ ) and as described previously [8].

Skin prick test (SPT). SPT was done for all study patients with standardized respiratory allergens (Stallergenes; London, UK) including Dermatophagoides Pteronyssius (Dp), Dermatophagoides Farinae (Df), Blomia tropicalis (Blo), Phoenix dactylisera, Alternaria spp, mixed pollens (Dactylus glomerata, Phleum pratense, Lolium perenne), dog hairs, cat hairs, and cockroaches. Negative control with $0.9 \%$ saline solution and positive control with $1 \mathrm{mg} / \mathrm{mL}$ of histamine was done for each SPT. The test was positive when the wheal size exceeded the negative control $\geq 3$ $\mathrm{mm}$.

Lung Function Testing (LFT). LFT (spirometry) was done by Blue Spiro (Medisoft; Sorinnes, Belgium). The reversibility of airway obstruction was measured by forced expiratory volume in one second (FEV1) after $15 \mathrm{~min}$ using $200 \mathrm{mcg}$ albuterol. The reversibility test was defined as positive when there was an increase of FEV1 $\geq 12 \%$ and $>200 \mathrm{~mL}$ as described previously $[8,24]$. The reference values and used equations were defined by integrated Expair Software (Medisoft; Sorinnes, Belgium) with race correction for Asian people. The level of obstruction was defined as mild obstruction (FEV1 $\geq 80 \%$ predicted, moderate obstruction (FEV1 of $60-79 \%$ predicted), and severe obstruction (FEV1 $<59 \%$ predicted). LFT was done routinely after the measurement of exhaled nitric oxide.

Exhaled nitric oxide (NO) measurements. FENO, CANO and $\mathrm{FnNO}$ were done by Hypair $\mathrm{FeNO}^{+}$Device (Medisoft; Sorinnes, Belgium) according to manufacturer's instructions as described previously with expiratory air flows of $50 \mathrm{~mL} / \mathrm{sec}$ for $F E N O$ and with multiple flows for $C A N O$ [8]. CANO was done by machine's integrated Expair Software using a linear equation of $\mathrm{y}=\mathrm{ax}+\mathrm{b}(\mathrm{x}$ : flow rate [4 flow rates of 50/100/150/350 mL/s]; b: JawNO 115 [maximal bronchial production of $\mathrm{NO}$ in the airways]; a: CANO). $C A N O$ and JawNO have been corrected according to the Condorelli equation [25]. The mean value of two correct measurements was used for analysis. $F E N O, C A N O$ and $F$ nNO levels were classified as recommended by the ATS (American Thoracic Society) / ERS (European Respiratory Society) and previous publications $[16,24,26]$.

\section{Statistical analysis}

The statistical analysis was performed with SPSS software 22.0 (Chicago, IL, USA) for all recorded data. Categorical variables were presented absolute and relative frequencies ( $\mathrm{n}$ and \%) and continuous variables were described by mean and standard deviation (mean $\pm \mathrm{SD}$ ). Normal distribution was evaluated by using Skewness-Kurtosis test. The pair-comparison of mean was done by Mann-Whitney U test or by Kruskal-Wallis test for more than two groups. Odds ratios (OR) with $95 \%$ confidence interval (CI) was used to measure the association between clinical and functional parameters at inclusion with controlled or uncontrolled asthma after 3 months. The $\mathrm{P}$ value $<0.05$ was considered as statistically significant.

\section{Results}

\section{Clinical and functional characteristic of study patients at inclusion}

From June 2018 to June 2019, 93 asthmatic children more than 6 years of age who met the inclusion criteria and followed-up dur- ing 3 months were included in the study (Figure 1). The mean age of patients was $9 \pm 3$ years; $62.4 \%$ male; and asthma onset age of $3.5 \pm 2.5$ years (Table 1 ). There were $54.8 \%$ passive smokers (exposed to second-hand smoke), $87.1 \%$ personal allergic history, and $62.3 \%$ had family history of allergies (Table 1 ). The percentage of moderate and severe asthma was respectively $63.4 \%$ and $36.6 \% .8 .6 \%, 59.1 \%$ and $32.3 \%$ of subjects were never treated, discontinued treatment or unregularly treated with an asthma preventive drug, respectively (Table 1).

Table 1. Clinical and functional characteristics of patients at the beginning of study.

\begin{tabular}{|c|c|}
\hline Characteristics ( $\mathrm{N}=93$ ) & $\begin{array}{l}\text { Mean } \pm \text { SD or } \\
\text { Percentage \% (N) }\end{array}$ \\
\hline Age, years & $9 \pm 3$ \\
\hline $\begin{array}{l}\text { Gender } \\
\text { Male } \\
\text { Female }\end{array}$ & $\begin{array}{r}62.4(58 \\
47.6(35)\end{array}$ \\
\hline Age of asthma onset, years & $3.5 \pm 2.5$ \\
\hline BMI, $\mathrm{kg} / \mathrm{m}^{2}$ & $17.5 \pm 1.5$ \\
\hline Passive smokers, $\%$ & $54.8(51)$ \\
\hline $\begin{array}{l}\text { Atopy } \\
\text { Personal allergic history } \\
\text { Familiar allergic history }\end{array}$ & $\begin{array}{l}87.1(81) \\
62.3(58)\end{array}$ \\
\hline $\begin{array}{l}\text { Asthma severity, } \% \\
\text { Moderate asthma } \\
\text { Severe asthma }\end{array}$ & $\begin{array}{l}63.4(59) \\
36.6(34)\end{array}$ \\
\hline AAE with hospitalization, times/year & $2.4 \pm 1.6$ \\
\hline $\begin{array}{l}\text { Asthma preventive treatment } \\
\text { Never treated with preventive drugs } \\
\text { Discontinued treatment } \\
\text { Unregularly treated }\end{array}$ & $\begin{array}{c}8.6(8) \\
59.1(55) \\
32.3(22)\end{array}$ \\
\hline ACT, scores & $8 \pm 4$ \\
\hline $\begin{array}{l}\text { Comorbidity } \\
\text { Allergic rhinitis } \\
\text { Eczema }\end{array}$ & $\begin{array}{l}83.8(78) \\
31.2(29)\end{array}$ \\
\hline $\begin{array}{l}\text { Spirometry } \\
\text { FEV }_{1}, \% \text { of predicted } \\
\text { FVC, \% of predicted } \\
\text { FEV/FVC, \% of predicted } \\
\text { FEF25-75, \% of predicted } \\
\text { PEFR, \% of predicted } \\
\text { Reversibility*, \% (N) }\end{array}$ & $\begin{array}{r}64 \pm 18 \\
73 \pm 12 \\
67 \pm 11 \\
48 \pm 19 \\
58 \pm 15 \\
76.3(71)\end{array}$ \\
\hline $\begin{array}{l}\text { Exhaled NO } \\
\text { FENO, ppb } \\
\text { CANO, ppb } \\
\text { JawNO, nL/min } \\
\text { FnNO, ppb }\end{array}$ & $\begin{array}{c}37 \pm 11 \\
5.8 \pm 1.4 \\
77 \pm 22 \\
1826 \pm 379\end{array}$ \\
\hline Total IgE, UI/mL & $1563 \pm 576$ \\
\hline 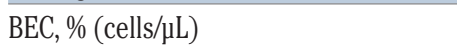 & $6.3 \pm 3.5(617 \pm 258)$ \\
\hline SPT $(+)^{\S}$ & 89 \\
\hline
\end{tabular}

BMI, body mass index; AAE, acute asthma exacerbation; ACT, asthma control test; $\mathrm{FEV}_{1}$, force expiratory volume in $1 \mathrm{~s}$; FVC, forced vital capacity; FEF25-75, forced expiratory flow at 25-75\% of time; $P E F R$, peak expiratory flow rate: $N O$, nitric oxide; $F E N O$, fractional concentration of exhaled nitric oxide; CANO, concentration of nitric oxide in the gas phase of the alveolar; JawNO, total flux of $\mathrm{NO}$ in the conducting airway compartment; $F \mathrm{nNO}$, fractional concentration of nasally aspirated nitric oxide; ppb: part per billion; BEC, blood eosinophil count; SPT, skin prick test; *defined by increase of $\mathrm{FEV}_{1}>12 \%$ and $200 \mathrm{~mL}$; positive at least with one allergen on skin prick test. 
The result of spirometry showed study subjects had a moderate to severe reduction of FEV1 and PEFR with mean values of $64 \pm 18 \%$ and $58 \pm 15 \%$, respectively (Table 1 ). The levels of $F E N O$, $C$ ANO, JawNO, and $F$ nNO were $37 \pm 11$ ppb, $5.8 \pm 1.4$ ppb, $77 \pm 22$ $\mathrm{nL} / \mathrm{min}$, and $1826 \pm 379 \mathrm{ppb}$, respectively. The mean of BEC was $617 \pm 258$ cells $/ \mu \mathrm{L}$ or $6.3 \pm 3.5 \%$ of total white blood cells; the level of total $\mathrm{IgE}$ was $1563 \pm 576 \mathrm{UI} / \mathrm{mL}$ (Table 1 ). $89 \%$ of study subjects were positive with at least one respiratory allergen confirmed by SPT.

Clinical and functional characteristics of study patients after asthma management

The results after one month of asthma treatment showed the percentage of passive smokers, moderate or severe asthma, and asthma treatment with high or moderate dose of ICS plus LABA were not significant different in comparison to at the beginning of study in study subjects $(47.3 \%, 72.1 \%, 27.9 \%, 27.9 \%$, and $72.1 \%$ vs $54.8 \%, 63.4 \%, 36.6 \%, 36.6 \%$, and $63.4 \%$; $\mathrm{P}>0.05$; Table 2 , Figure 2). The daily use of SABA and ACT scores were significantly improved after one month compared to at inclusion in study patients ( $3.5 \pm 1.7$ and $15 \pm 6$ vs $6.2 \pm 3.4$ and $8 \pm 4 ; \mathrm{P}<0.05$ and $\mathrm{P}<0.01$, respectively; Table 2). The percentage of uncontrolled asthma was significantly reduced after one month in comparison to at inclusion (49.5\% vs $100 \%$; $\mathrm{P}<0.001$; Table 2, Figure 2). After one month of asthma treatment, there was significant improvement of spirometric parameters (Table 2). The levels of FENO, CANO, $J$ awNO, and $F \mathrm{nNO}$ were significant reduced after one month in compared to at inclusion $(25 \pm 12 \mathrm{ppb}, 4.9 \pm 2.1 \mathrm{ppb}, 41 \pm 16 \mathrm{~nL} / \mathrm{min}$, and $1432 \pm 561 \mathrm{ppb}$ vs $37 \pm 11 \mathrm{ppb}, 5.8 \pm 1.4 \mathrm{ppb}$ and $1826 \pm 379 \mathrm{ppb}$; $\mathrm{P}<0.01, \mathrm{P}<0.05$ and $\mathrm{P}<0.05$, respectively; Table 2 ).

The results after 3 months of asthma treatment showed there were significant reductions of severe asthma, weekly use of SABA, high dose of ICS + LABA, LTRA treatment, and uncontrolled asthma in comparison to at inclusion and after one month of treatment $(13.9 \%, 2.6 \pm 1.5$ times, $13.9 \%$, and $66.5 \%$ vs $36.6 \%$ and

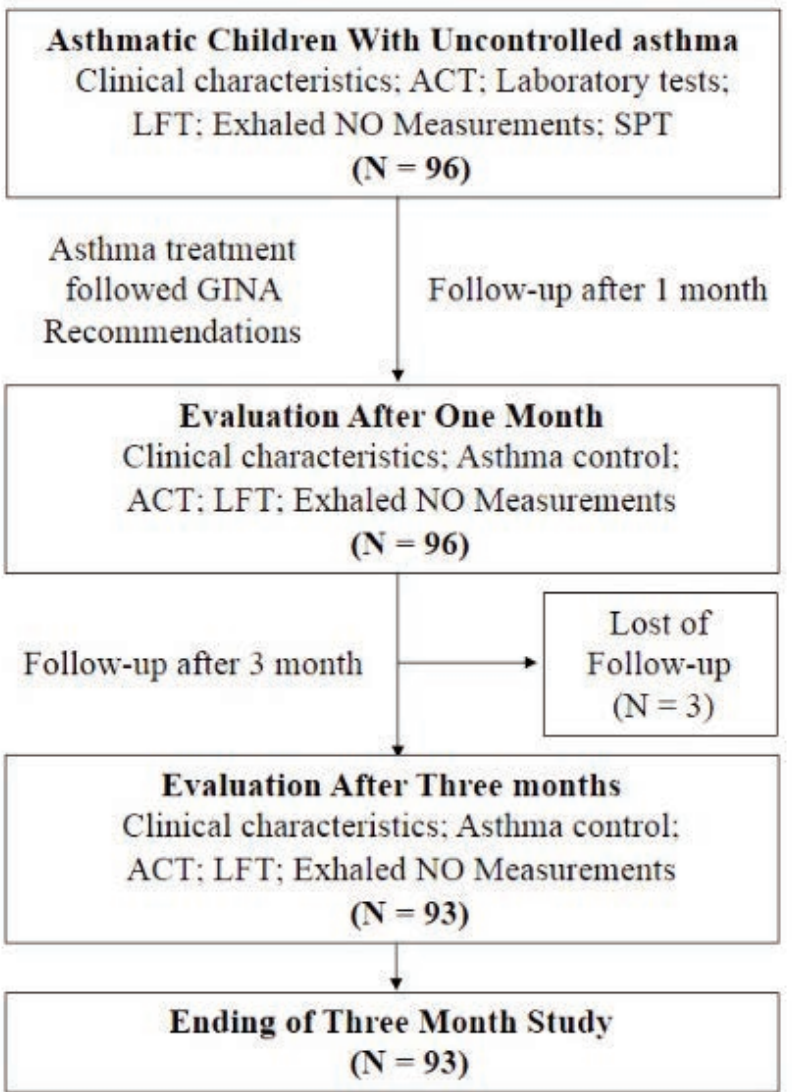

Figure 1. Flow chart of study with asthmatic children after three months followed-up. ACT, Asthma Control Test; LFT, lung function test; NO, nitric oxide; SPT, skin prick test.

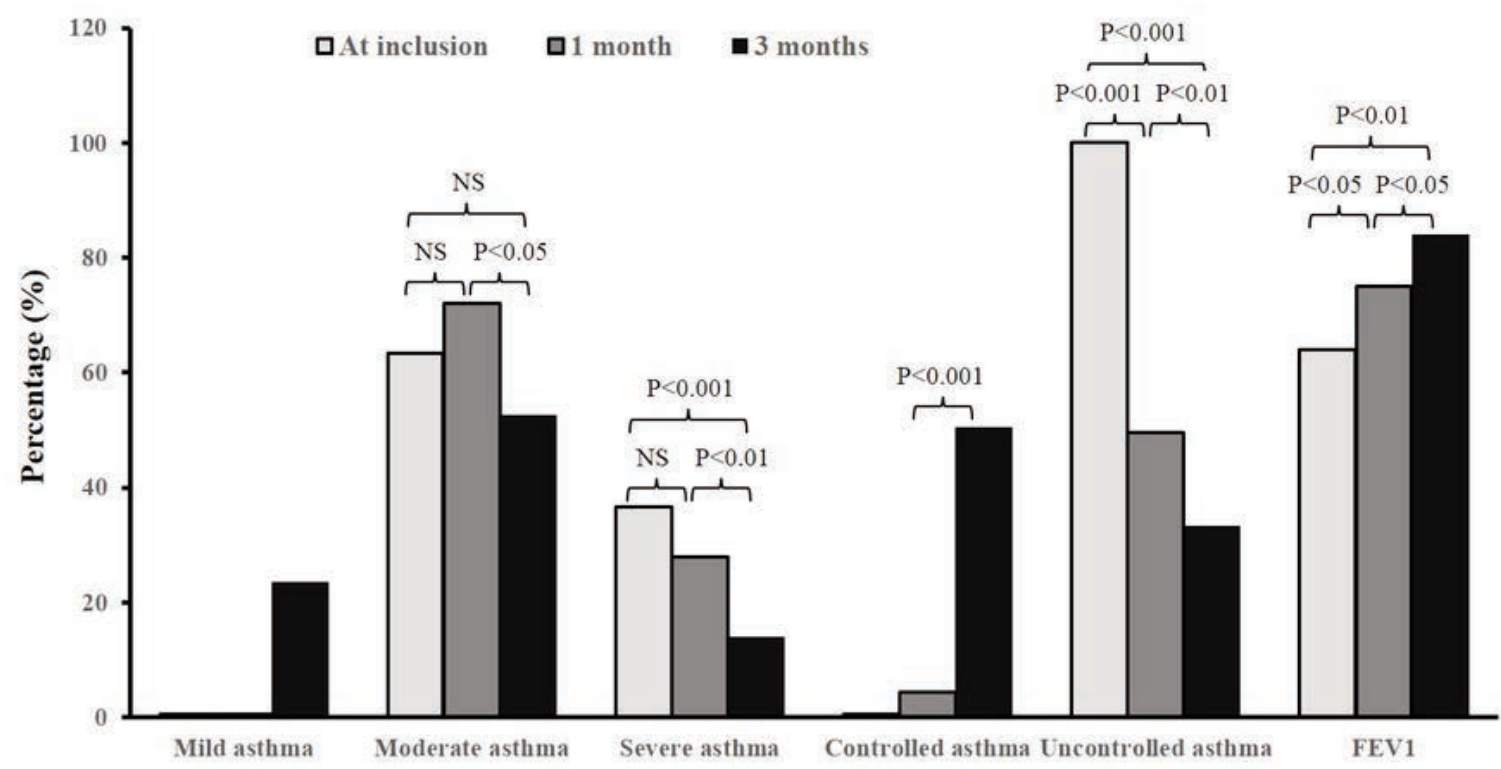

Figure 2. Significant modification of clinical and functional characteristics of study patients after 1 month and 3 months. FEV , forced expiratory volume; NS, not significant difference. 
$27.9 \%, 6.2 \pm 3.4$ and $3.5 \pm 1.7$ times, $36.6 \%$ and $27.9 \%$, and $100 \%$ and $100 \% ; \mathrm{P}<0.001$ and $\mathrm{P}<0.01, \mathrm{P}<0.01$ and $\mathrm{P}<0.05, \mathrm{P}<0.001$ and $\mathrm{P}<0.01$, and $\mathrm{P}<0.001$ and $\mathrm{P}<0.001$, respectively; Table 2, Figure 2 ). The ACT scores and percentage of controlled asthma were also significantly increased after 3 months of treatment in comparison to at inclusion and after one month of treatment $(19 \pm 5$ vs $8 \pm 4$ and $15 \pm 6 ; 50.5 \%$ vs $0 \%$ and $4.3 \% ; \mathrm{P}<0.001$ and $\mathrm{P}<0.05 ; \mathrm{P}<0.001$, respectively; Table 2, Figure 2). There was the significant improvement of FEV1 and PEFR after 3 months of treatment compared to at inclusion $(\mathrm{P}<0.01$ and $\mathrm{P}<0.01$, respectively; Table 2). The levels of $F \mathrm{ENO}, C \mathrm{ANO}$, and $F \mathrm{nNO}$ were also significantly reduced after 3 months of treatment in comparison to at inclusion and after one month of treatment $(16 \pm 9$ ppb vs $37 \pm 11$ and $25 \pm 12$ ppb, $3.7 \pm 1.8 \mathrm{ppb} v \mathrm{~s} 5.8 \pm 1.4$ and $4.9 \pm 2.1 \mathrm{ppb}$, and $978 \pm 425$ vs $1826 \pm 379$ and $1432 \pm 561 \mathrm{ppb} ; \mathrm{P}<0.001$ and $\mathrm{P}<0.01, \mathrm{P}<0.01$ and $\mathrm{P}<0.05$, and $\mathrm{P}<0.001$ and $\mathrm{P}<0.01$, respectively; Table 2 ).

Comparison of clinical and functional characteristics at inclusion between uncontrolled and controlled asthmatic patients at 3 months

The results of present study showed there was no significant difference between controlled and uncontrolled asthmatic patients classified at 3 months for age, gender, BMI, and atopy measured at inclusion $\left(9 \pm 2\right.$ vs $8 \pm 3,29 \%$ vs $20 \%, 17.3 \pm 1.4$ vs $17.9 \pm 1.6 \mathrm{~kg} / \mathrm{m}^{2}$,
$87.2 \%$ vs $80.6 \% ; \mathrm{P}>0.05, \mathrm{P}>0.05, \mathrm{P}>0.05$, and $\mathrm{P}>0.05$, respectively; Table 3). Controlled asthmatic patients were older and had moderate asthma severity at inclusion than uncontrolled asthmatic patients $(5.5 \pm 2.0$ vs $2.5 \pm 1.5$ and $80.8 \%$ vs $25.8 \%$; $\mathrm{P}<0.01$ and $\mathrm{P}<0.001$, respectively; Table 3, Figure 3).

In comparison to uncontrolled asthmatic patients, study patients with controlled asthma at 3 months had higher FEV1, PEFR, and FENO levels at inclusion than those with uncontrolled asthma $(78 \pm 19 \%$ vs $52 \pm 16 \%, 69 \pm 17 \%$ vs $46 \pm 12 \%$, and $45 \pm 14 \mathrm{ppb}$ vs $29 \pm 8$ ppb; $\mathrm{P}<0.05, \mathrm{P}<0.05$, and $\mathrm{P}<0.05$, respectively; Table 3 , Figure 3$)$. Controlled asthma also had a higher reversibility rate than uncontrolled asthma (91.4\% vs 54.8\%, $\mathrm{P}<0.01$; Table 3). Uncontrolled asthmatic patients at 3 months had a higher level of $C \mathrm{ANO}, \mathrm{nNO}$, total IgE, and BEC at inclusion than controlled asthmatic patients $(6.9 \pm 1.9 \mathrm{ppb}$ vs $4.7 \pm 0.8 \mathrm{ppb}, 2341 \pm 487 \mathrm{ppb} v s$ $1322 \pm 256 \mathrm{ppb}, 2154 \pm 785 \mathrm{UI} / \mathrm{mL}$ vs $1143 \pm 437 \mathrm{UI} / \mathrm{mL}$, and $823 \pm 367$ cells $/ \mu \mathrm{L} v s 451 \pm 184$ cells $/ \mu \mathrm{L} ; \mathrm{P}<0.05, \mathrm{P}<0.01, \mathrm{P}<0.01$, and $\mathrm{P}<0.05$, respectively; Table 3 ).

Odds ratios and $95 \%$ confidence intervals for the predictive factors at inclusion on controlled and uncontrolled asthma at 3 months

The severity of asthma evaluated at inclusion had a significant odd ratio (OR) for the control of asthma defined by GINA or ACT

Table 2. Comparison of clinical and functional characteristics at the beginning of study vs after 1 month and 3 months..

\begin{tabular}{|c|c|c|c|c|}
\hline Characteristics & $\begin{array}{l}\text { At inclusion } \\
(\mathrm{N}=93)\end{array}$ & $\begin{array}{l}1 \text { month } \\
(\mathrm{N}=93)\end{array}$ & $\begin{array}{c}3 \text { months } \\
(\mathrm{N}=93)\end{array}$ & $\mathbf{P}$ \\
\hline Passive smokers, \% (N) & $54.8(51)$ & $47.3(44)$ & $44.1(41)$ & $\mathrm{NS}^{\sharp}, \S_{,}^{\circ}$ \\
\hline $\begin{array}{l}\text { Asthma severity, \% } \\
\text { Mild asthma } \\
\text { Moderate asthma } \\
\text { Severe asthma }\end{array}$ & $\begin{array}{c}0(0) \\
63.4(59) \\
36.6(34)\end{array}$ & $\begin{array}{c}0 \\
72.1(67) \\
27.9(26)\end{array}$ & $\begin{array}{l}23.5(31) \\
52.6(49) \\
13.9(13)\end{array}$ & 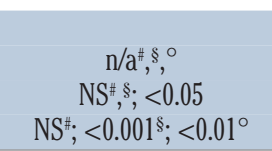 \\
\hline Use of SABA, times/week & $6.2 \pm 3.4$ & $3.5 \pm 1.7$ & $2.6 \pm 1.5$ & $<0.05^{\#} ;<0.01^{\S} ;<0.05^{\circ}$ \\
\hline $\begin{array}{l}\text { Asthma treatment* } \\
\text { High dose of ICS+LABA } \\
\text { Moderate dose of ICS+LABA } \\
\text { LTRA } \\
\text { Moderate dose of ICS }\end{array}$ & $\begin{array}{c}36.6(34) \\
63.4(59) \\
100(93) \\
0(0)\end{array}$ & $\begin{array}{c}27.9(26) \\
72.1(67) \\
100(93) \\
0(0)\end{array}$ & $\begin{array}{l}13.9(13) \\
52.6(49) \\
66.5(62) \\
23.5(31)\end{array}$ & $\begin{array}{c}\mathrm{NS}^{\#} ;<0.001^{\S ;} ;<0.01^{\circ} \\
\mathrm{NS}^{\#}, ; ;<0.01^{\circ} \\
\mathrm{NS}^{\# ;}<<0.001^{\S} ;<0.001^{\circ} \\
\mathrm{n} / \mathrm{a}^{\#},{ }^{\S},\end{array}$ \\
\hline ACT, scores & $8 \pm 4$ & $15 \pm 6$ & $19 \pm 5$ & $<0.01^{\sharp ;} ;<0.001^{\S} ;<0.05^{\circ}$ \\
\hline $\begin{array}{l}\text { Control of asthma } \\
\text { Uncontrolled, \% } \\
\text { Partially controlled, \% } \\
\text { Total controlled, \% }\end{array}$ & $\begin{array}{l}100(93) \\
0(0) \\
0(0)\end{array}$ & $\begin{array}{c}49.5(46) \\
46.2(43) \\
4.3(4)\end{array}$ & $\begin{array}{l}33.3(31) \\
16.1(15) \\
50.5(47)\end{array}$ & $\begin{array}{c}<0.001^{\sharp} ;<0.001^{\S} ;<0.01^{\circ} \\
\mathrm{n} / \mathrm{a}^{\#}, \S ;<0.001^{\circ} \\
\mathrm{n} / \mathrm{a}^{\#}, \S ;<0.001^{\circ}\end{array}$ \\
\hline $\begin{array}{l}\text { Treatment adherence } \\
\text { Good } \\
\text { Poor }\end{array}$ & $\begin{array}{c}0(0) \\
100(93)\end{array}$ & $\begin{array}{l}87.1(81) \\
12.9(12)\end{array}$ & $\begin{array}{c}100(93) \\
0(0)\end{array}$ & $\begin{array}{l}\mathrm{n} / \mathrm{a}^{\#},{ }^{\S ;}<0.001^{\circ} \\
<0.001^{\sharp ;} ; \mathrm{n} / \mathrm{a}^{\S},\end{array}$ \\
\hline $\begin{array}{l}\text { Spirometry, \% of predicted } \\
\text { FEV }_{1} \\
\text { FVC } \\
\text { FEV1/FVC } \\
\text { FEF25-75 } \\
\text { PEFR }\end{array}$ & $\begin{array}{l}64 \pm 18 \\
73 \pm 12 \\
67 \pm 11 \\
48 \pm 19 \\
58 \pm 15\end{array}$ & $\begin{array}{c}75 \pm 12 \\
81 \pm 14 \\
78 \pm 8 \\
59 \pm 15 \\
77 \pm 12\end{array}$ & $\begin{array}{l}84 \pm 14 \\
88 \pm 11 \\
81 \pm 12 \\
64 \pm 12 \\
81 \pm 11\end{array}$ & $\begin{array}{l}<0.05^{\#} ;<0.01^{\S} ;<0.05^{\circ} \\
<0.05^{\#} ;<0.05^{\S} ; \mathrm{NS}^{\circ} \\
<0.05^{\# ;}<0.01^{\S} ; \mathrm{NS}^{\circ} \\
<0.05^{\#} ;<0.05^{\S} ; \mathrm{NS}^{\circ} \\
<0.01^{\# ;} ;<0.01^{\S} ; \mathrm{NS}^{\circ}\end{array}$ \\
\hline $\begin{array}{l}\text { Exhaled NO } \\
\text { FENO, ppb } \\
\text { CANO, ppb } \\
\text { JawNO, nL/min } \\
\text { FnNO, ppb } \\
\end{array}$ & $\begin{array}{c}37 \pm 11 \\
5.8 \pm 1.4 \\
77 \pm 22 \\
1826 \pm 379\end{array}$ & $\begin{array}{c}25 \pm 12 \\
4.9 \pm 2.1 \\
41 \pm 16 \\
1432 \pm 561\end{array}$ & $\begin{array}{c}16 \pm 9 \\
3.7 \pm 1.8 \\
38 \pm 13 \\
978 \pm 425\end{array}$ & $\begin{array}{l}<0.01^{\sharp} ;<0.001^{\S} ; 0.01^{\circ} \\
<0.05^{\sharp ;} ;<0.01^{\S} ; 0.05^{\circ} \\
<0.01^{\sharp} ;<0.001^{\S} ; N S^{\circ} \\
<0.05^{\sharp} ;<0.001^{\S} ; 0.01^{\circ}\end{array}$ \\
\hline
\end{tabular}

SABA, short acting beta 2 agonist; ICS, inhaled corticosteroid; LABA, long acting beta 2 agonist; LTRA, leukotriene receptor antagonist; ACT, asthma control test; FEV 1 , forced expiratory volume in 1 second; FVC, forced vital capacity; FEF25-75, forced expiratory flow at 25-75\% of time; PEFR, peak expiratory flow rate; NO, nitric oxide; FENO, fractional exhaled nitric oxide; CANO, concentration of nitric oxide in the gas phase of the alveolar; JawNO, total flux of NO in the conducting airway compartment; FnNO, fractional concentration of nasally aspirated nitric oxide; ppb: part per billion; *treatment started at the beginning of study; ${ }^{*}$ at the beginning us 1 month; ${ }^{\S}$ at the beginning us 3 months; 3 months us 1 month. 
scores $>20$ (Table 4, Figure 4). The medical history of hospitalization due to asthma exacerbation in previous year had significant and negative OR for uncontrolled asthma defined by GINA at 3 months $(\mathrm{OR}=1.9$ and $\mathrm{P}<0.05$; Table 4, Figure 4). Asthmatic patients who had allergic rhinitis also had significant OR for asthma control defined by ACT scores $(\mathrm{OR}=1.4$ and $\mathrm{P}<0.05)$. FEV1 $<60 \%$ of predicted value at inclusion had a risk of uncontrolled asthma in study subjects ( $\mathrm{OR}=1.8$ and $\mathrm{P}<0.05)$. FEV $1 \geq 80 \%$ of predicted value at inclusion had a good agreement of OR for asthma control defined by both criteria of GINA and ACT scores (OR $=1.6$ and $\mathrm{P}<0.05 ; \mathrm{OR}=1.5$ and $\mathrm{P}<0.05$, respectively; Table 4, Figure 4). FENO $<20 \mathrm{ppb}$ had a risk of uncontrolled asthma at 3 months in study patients $(\mathrm{OR}=1.7$ and $1.5 ; \mathrm{P}<0.05$ and $\mathrm{P}<0.05$; Table 4, Figure 4). However, FENO $>35$ ppb had a good agreement for asthma control defined by GINA $(\mathrm{OR}=3.5$ and $\mathrm{P}<0.01)$ whereas $C A N O>5$ ppb had a risk of asthma control defined by GINA and ACT scores at 3 months (Table 4, Figure 4).

\section{Discussion}

The results of this study showed that i) the cut-off of FENO $<20 \mathrm{ppb}$ or $C$ ANO $>5 \mathrm{ppb}$ demonstrated a risk of uncontrolled asthma at 3 months in study patients; ii) the level of FENO and CANO, percentage of uncontrolled asthma, daily use of SABA were significantly reduced after one and three months of asthmatic treatment; 3) the controlled asthmatic subjects evaluated at three months had higher levels of $F E N O$ and $C A N O$ and lower percentages of severe asthma and hospitalization frequency in previous year measured at inclusion than uncontrolled asthmatic subjects.

The asthmatic children in this study had the general characteristics of asthma in childhood with early asthma onset $(<5$ yearsold) and medical history of allergy and atopy (Table 1 ). The percentage of second-hand smoke exposure in asthmatic subjects was very high $(54.8 \%$; Table 1$)$; however, there was no significant difference of $F E N O$ level in subjects with or without passive smoking ( $36 \pm 10 \mathrm{ppb}$ vs $38 \pm 11 \mathrm{ppb}$; data not shown). BobrowskaKorzeniowska et al. have suggested that FENO measurement could be interpreted in the context of environmental tobacco smoke exposure in asthmatic children [27]. Second-hand smoke exposure is a significant and complicating factor for asthma management in children in emerging countries such as Vietnam where the prevalence of adult smokers is high [28]. Asthmatic children exposed to tobacco smoke (passive smoking / second-hand smokers) are at higher risk for uncontrolled asthma with more severe asthma symptoms and exacerbations $[29,30]$. Therefore, cigarette smoking avoidance in childhood asthma education should be highly emphasized.

The present study showed that at inclusion, the majority of subjects had moderate asthma and their asthma treatment was discontinued or irregular; and especially, they had high levels of $F E N O, C A N O$, and FnNO (Table 1, Figure 3). Although the use of $F E N O$ in diagnosis and treatment of Type 2 asthma has been recommended previously $[1,7,31]$, its role in predicting the control of asthma in children in short-term follow-up has not been well demonstrated. In asthmatic patients, the level of airway inflammation measured by FENO may be used to step-up (with increased $F \mathrm{ENO}$ ) or step-down (with decreased FENO) the dose of ICS treatment $[8,18,26,32]$. A recent study of ours showed that the use of $F \mathrm{ENO}$ in combination with GINA recommendations may help to reduce the dose of ICS $v s$ using GINA alone in asthmatic children [8]. In the present study, the level of $F \mathrm{ENO}$ and $C A N O$ has been reduced after asthma treatment at one month and three months (Table 2). Interestingly, our study found that a reduction of $F E N O$ and $C A N O$ was associated with an increase percentage of subjects with controlled asthma (Table 2). Therefore, the reduction of $F \mathrm{ENO}$ and $C A N O$ level might predict the responsiveness of asthma treatment in patients who are naïve to ICS. However, the results of our study showed that JawNO level was significantly reduced after one month but not after three months and especially there was no significant difference of JawNO level between controlled asthma vs uncontrolled asthma at inclusion (Tables 2 and 3) Although the

Table 3. Comparison of clinical and functional characteristics at the beginning of study between controlled and uncontrolled asthma patients classified at 3 months.

\begin{tabular}{|c|c|c|c|}
\hline Characteristics & $\begin{array}{l}\text { Uncontrolled } \\
\text { asthma } \\
(\mathrm{N}=31)\end{array}$ & $\begin{array}{l}\text { Total } \\
\text { controlled } \\
\text { asthma } \\
(\mathrm{N}=47)\end{array}$ & $\mathbf{P}$ \\
\hline Age, years & $8 \pm 3$ & $9 \pm 2$ & NS \\
\hline $\begin{array}{l}\text { Gender } \\
\quad \text { Male } \\
\text { Female }\end{array}$ & $\begin{array}{l}20 \\
11\end{array}$ & $\begin{array}{l}29 \\
18\end{array}$ & $\begin{array}{l}\text { NS } \\
\text { NS }\end{array}$ \\
\hline Age of asthma onset, years & $2.5 \pm 1.5$ & $5.5 \pm 2.0$ & $<0.01$ \\
\hline BMI, $\mathrm{kg} / \mathrm{m}^{2}$ & $17.9 \pm 1.6$ & $17.3 \pm 1.4$ & NS \\
\hline Passive smokers, $\%$ & $61.3(19)$ & $38.2(18)$ & $<0.05$ \\
\hline $\begin{array}{l}\text { Atopy } \\
\text { Personal allergic history } \\
\text { Familiar allergic history }\end{array}$ & $\begin{array}{l}80.6(25) \\
58.1(18)\end{array}$ & $\begin{array}{l}87.2(41) \\
61.7(29)\end{array}$ & $\begin{array}{l}\text { NS } \\
\text { NS }\end{array}$ \\
\hline $\begin{array}{l}\text { Asthma severity, } \% \\
\text { Moderate asthma } \\
\text { Severe asthma }\end{array}$ & $\begin{array}{c}25.8(8) \\
74.2(23)\end{array}$ & $\begin{array}{c}80.8(38) \\
19.2(9)\end{array}$ & $\begin{array}{l}<0.001 \\
<0.001\end{array}$ \\
\hline AAE with hospitalization, times/year & ar $3.2 \pm 1.8$ & $1.8 \pm 0.9$ & $<0.05$ \\
\hline $\begin{array}{l}\text { Asthma treatment* } \\
\text { High dose of ICS+LABA } \\
\text { Moderate dose of ICS+LABA } \\
\text { LTRA } \\
\text { Moderate dose of ICS } \\
\text { Use of SABA, times/week }\end{array}$ & $\begin{array}{c}74.2(23) \\
25.8(8) \\
100(31) \\
0(0) \\
8.5 \pm 2.6\end{array}$ & $\begin{array}{c}19.2(9) \\
80.8(38) \\
100(47) \\
0(0) \\
2.4 \pm 1.3\end{array}$ & $\begin{array}{l}<0.001 \\
<0.001 \\
\mathrm{NS} \\
\mathrm{n} / \mathrm{a} \\
<0.001\end{array}$ \\
\hline $\begin{array}{l}\text { Comorbidity } \\
\text { Allergic rhinitis } \\
\text { Eczema }\end{array}$ & $\begin{array}{l}90.3(28) \\
29.0(9)\end{array}$ & $\begin{array}{l}65.9(31) \\
31.9(15)\end{array}$ & $\begin{array}{c}<0.01 \\
\mathrm{NS}\end{array}$ \\
\hline $\begin{array}{l}\text { Spirometry } \\
\text { FEV }_{1}, \% \text { of predicted } \\
\text { FVC, \% of predicted } \\
\text { FEV }_{1} / \text { FVC, \% of predicted } \\
\text { FEF25-75, \% of predicted } \\
\text { PEFR, \% of predicted } \\
\text { Reversibility }, \%(\mathrm{~N})\end{array}$ & $\begin{array}{c}52 \pm 16 \\
69 \pm 11 \\
66 \pm 9 \\
46 \pm 17 \\
46 \pm 12 \\
54.8(17)\end{array}$ & $\begin{array}{r}78 \pm 19 \\
79 \pm 14 \\
69 \pm 12 \\
51 \pm 21 \\
69 \pm 17 \\
91.4(43)\end{array}$ & $\begin{array}{l}<0.05 \\
\text { NS } \\
\text { NS } \\
\text { NS } \\
<0.05 \\
<0.01\end{array}$ \\
\hline $\begin{array}{l}\text { Exhaled NO, ppb } \\
\text { FENO, ppb } \\
\text { CANO, ppb } \\
\text { JawNO, nL/min } \\
\text { FnNO, ppb }\end{array}$ & $\begin{array}{c}29 \pm 8 \\
6.9 \pm 1.9 \\
79 \pm 23 \\
2341 \pm 487\end{array}$ & $\begin{array}{c}45 \pm 14 \\
4.7 \pm 0.8 \\
75 \pm 21 \\
1322 \pm 256\end{array}$ & $\begin{array}{l}<0.05 \\
<0.05 \\
\mathrm{NS} \\
<0.01\end{array}$ \\
\hline Total IgE, UI/mL & $2154 \pm 785$ & $1143 \pm 437$ & $<0.01$ \\
\hline 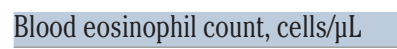 & $823 \pm 367$ & $451 \pm 184$ & $<0.05$ \\
\hline Skin prick test $(+)^{\circ}$ & $83.9(26)$ & $80.8(38)$ & NS \\
\hline
\end{tabular}

BMI, body mass index; AAE, acute asthma exacerbation; SABA, short acting beta 2 agonist; ICS: inhaled corticosteroid; LABA, long acting beta 2 agonist; LTRA, leukotriene receptor antagonist: $\mathrm{FEV}_{1}$, forced expiratory volume in $1 \mathrm{~s}$; FVC, forced vital capacity; FEF25-75, forced expiratory flow at $25-75 \%$ of time; PEFR, peak expiratory flow rate; NO, nitric oxide; $F$ ENO, fractional exhaled nitric oxide; CANO, concentration of nitric oxide in the gas phase of the alveolar; JawNO, total flux of NO in the conducting airway compartment; $F$ nNO, fractional concentration of nasally aspirated nitric oxide; ppb: part per billion; BEC, blood eosinophil count; SPT, skin prick test; *treatment started at inclusion; ${ }^{8}$ defined by increase of $\mathrm{FEV}_{1}>12 \%$ and $200 \mathrm{~mL} ;{ }^{\circ}$ positive at least with one allergen on skin prick test; NS, not significant difference. 
Multidisciplinary Respiratory Medicine 2020; 15:656 - X. Ngo-Minh et al.

use of FENO in patients with asthma, especially in severe asthma, has been considered currently as biomarker of ICS and biologic therapy [33], the use of CANO in asthma is still controversial. The results of recent studies suggest $C A N O$ might be used as a biomarker of distal airways in asthmatic patients [33-35]. Therefore, $C$ ANO has been considered as an additional tool to categorize asthmatic children who have atopy and are sensitive to ICS [33]. A previous study demonstrated the level of CANO was higher in asthmatic children than that in healthy subjects and it was related to asthma control and depended on alveolar inflammation [35]. It has been suggested that an increase of $C A N O$ level could reflect a severe or persistent asthma $[21,23]$. Until now, the phenotype of asthmatic children with high level of $C A N O$ has not been well clarified. Increased $C A N O$ in exhaled breath might reflect the allergic inflammation in small airways in patients with asthma whereas it has been reduced in patients with lung fibrosis or pulmonary hypertension [36]. In adults, the increase of $C A N O$ level could reflect a severe or persistent asthma during asthma follow-up $[7,30]$. Thus, the reduction of CANO may be used as a predictive biomarker of the responsiveness of ICS treatment in asthmatic children with increased exhaled NO.

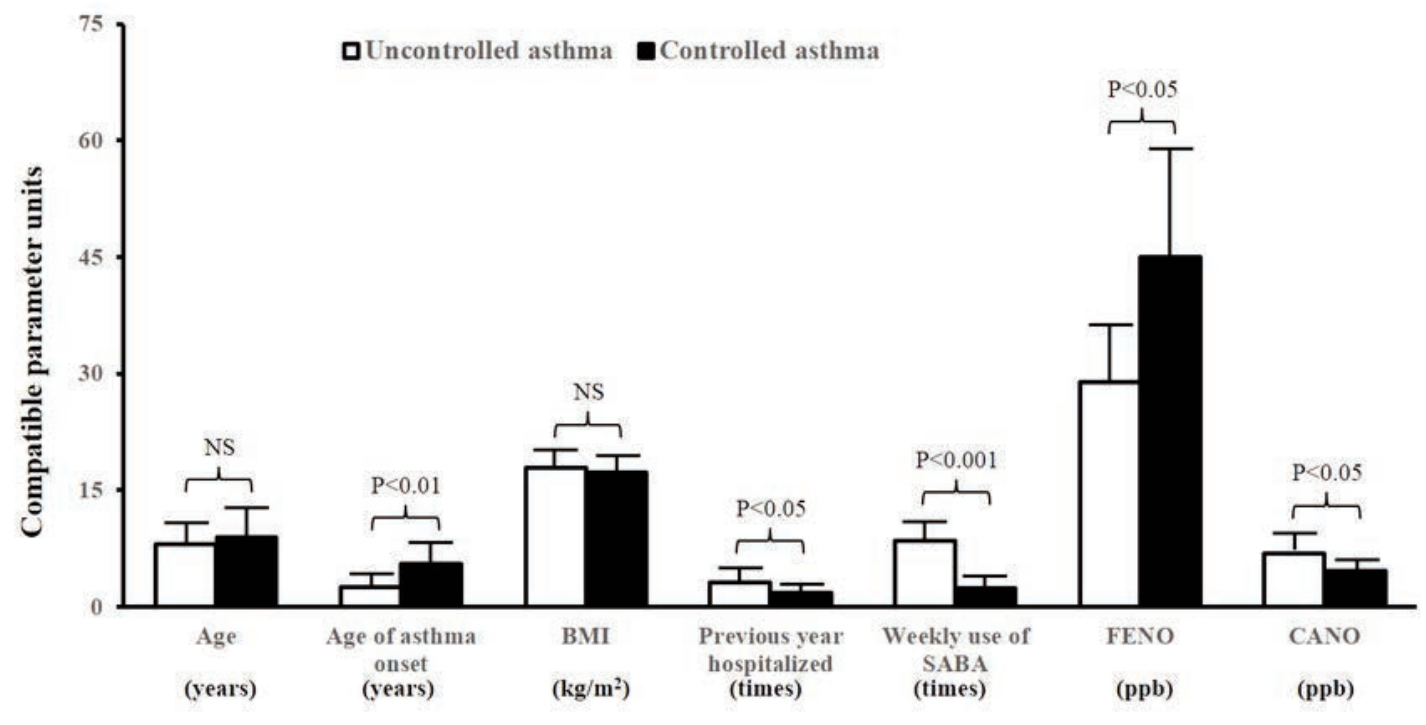

Figure 3. Comparison of clinical and functional characteristics measured at inclusion of controlled and uncontrolled asthma at 3 months. BMI, body mass index; FENO, fractional exhaled nitric oxide; CANO, concentration of alveolar nitric oxide; NS, not significant difference.

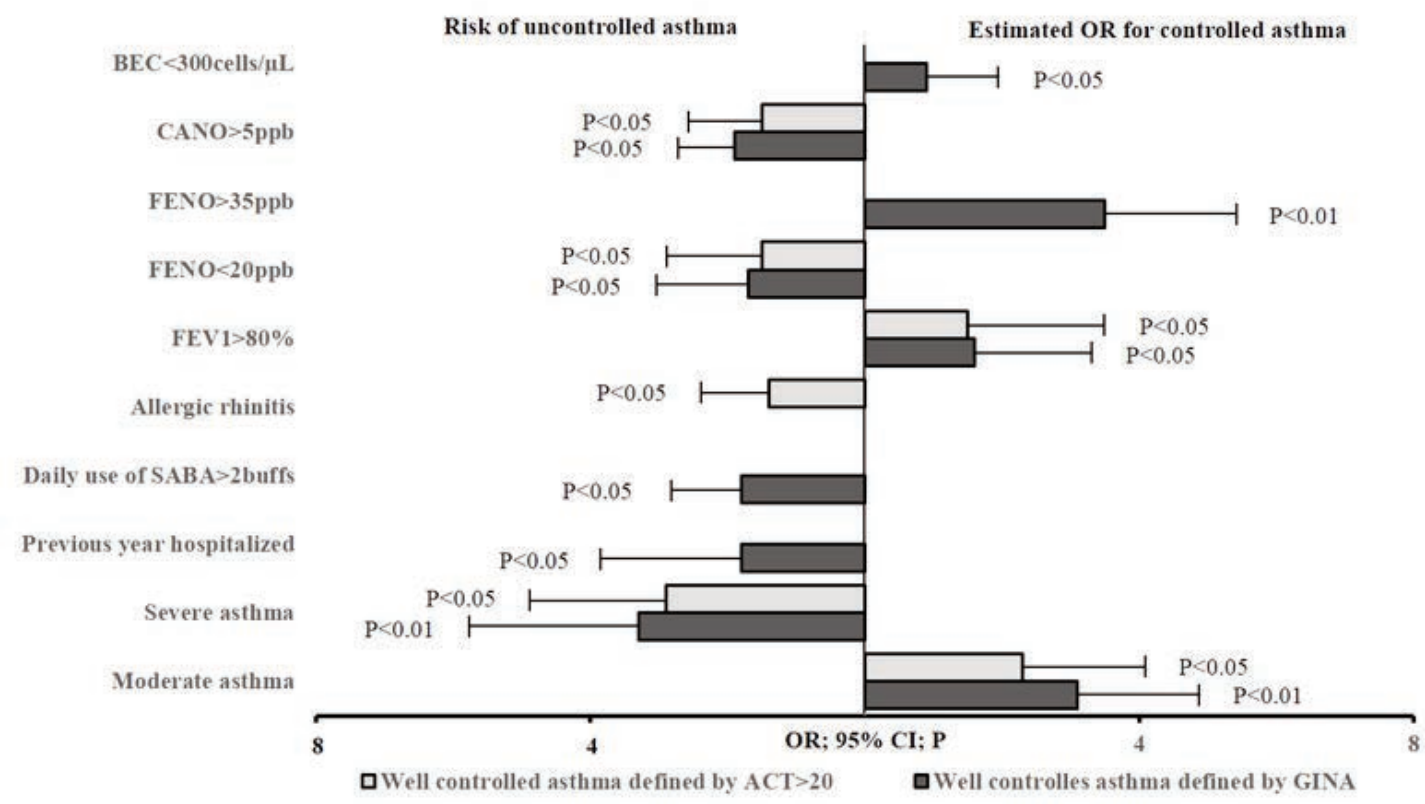

Figure 4. Odds ratios (OR) and $95 \%$ confidence intervals $(\mathrm{CI})$ for the predictive factors at inclusion on controlled and uncontrolled asthma at 3 months. BEC, blood eosinophil count; FENO, fractional exhaled nitric oxide; CANO, concentration of alveolar nitric oxide; $\mathrm{FEV}_{1}$, forced expiratory in one second; SABA, short acting beta 2 agonist. 
Multidisciplinary Respiratory Medicine 2020; 15:656 - X. Ngo-Minh et al.

Table 4. Odds ratios (OR) and $95 \%$ confidence intervals for the predictive factors at inclusion on controlled and uncontrolled asthma at 3 months.

\begin{tabular}{|c|c|c|c|c|c|c|c|}
\hline \multirow{3}{*}{\multicolumn{2}{|c|}{ Parameters }} & \multicolumn{6}{|c|}{ Well controlled asthma } \\
\hline & & \multicolumn{3}{|c|}{ Defined by GINA } & \multicolumn{3}{|c|}{ Defined by ACT scores $\geq 20$} \\
\hline & & $\begin{array}{c}\text { OR } \\
(\min / \max )\end{array}$ & CI 95\% & $\mathbf{P}$ & OR & CI 95\% & $\mathbf{P}$ \\
\hline \multicolumn{8}{|c|}{ Clinical characteristics* } \\
\hline \multicolumn{2}{|c|}{ Asthma onset >5 years $(+)$} & 1.3 & $0.5 / 1.8$ & NS & 1.5 & $0.8 / 1.9$ & NS \\
\hline \multicolumn{2}{|c|}{ Passive smoker (-) } & 1.4 & $0.7 / 2.1$ & NS & 1.3 & $0.7 / 1.8$ & NS \\
\hline Asthma severity & $\begin{array}{l}\text { Moderate }(+) \\
\text { Severe }(-)\end{array}$ & $\begin{array}{l}3.1 \\
3.3\end{array}$ & $\begin{array}{l}1.8 / 5.3 \\
1.7 / 5.9\end{array}$ & $\begin{array}{l}<0.01 \\
<0.01\end{array}$ & $\begin{array}{l}2.3 \\
2.9\end{array}$ & $\begin{array}{l}1.6 / 4.1 \\
1.4 / 4.8\end{array}$ & $\begin{array}{l}<0.05 \\
<0.05\end{array}$ \\
\hline \multicolumn{2}{|c|}{ AAE hospitalized in previous year $\geq 2$ times (-) } & 1.9 & $0.9 / 2.9$ & $<0.05$ & 1.7 & $0.6 / 3.1$ & NS \\
\hline \multicolumn{2}{|c|}{ Daily used $\mathrm{SABA} \geq 2$ buffs $^{\S}(-)$} & 1.8 & $0.8 / 2.7$ & $<0.05$ & 1.5 & $0.7 / 2.7$ & NS \\
\hline \multicolumn{2}{|c|}{ Allergic rhinitis (-) } & 1.5 & $0.7 / 2.9$ & NS & 1.4 & $0.7 / 2.4$ & $<0.05$ \\
\hline \multicolumn{8}{|c|}{ Functional characteristics* } \\
\hline $\mathrm{FEV}_{1}, \%$ & $\begin{array}{l}<60(-) \\
60-80(+) \\
\geq 80(+)\end{array}$ & $\begin{array}{l}1.8 \\
0.9 \\
1.6\end{array}$ & $\begin{array}{l}0.1 / 4.1 \\
0.5 / 2.1 \\
0.9 / 3.2\end{array}$ & $\begin{array}{l}<0.05 \\
\text { NS } \\
<0.05\end{array}$ & $\begin{array}{l}1.4 \\
0.7 \\
1.5\end{array}$ & $\begin{array}{l}0.9 / 3.9 \\
0.2 / 1.9 \\
0.7 / 3.8\end{array}$ & $\begin{array}{c}\mathrm{NS} \\
\mathrm{NS} \\
<0.05\end{array}$ \\
\hline nNO, ppb & $\begin{array}{l}>500(-) \\
500-1000(-) \\
>1000(-)\end{array}$ & $\begin{array}{l}1.4 \\
1.5 \\
1.3 \\
\end{array}$ & $\begin{array}{l}0.7 / 3.5 \\
0.5 / 3.1 \\
0.7 / 3.1\end{array}$ & $\begin{array}{l}\text { NS } \\
\text { NS } \\
\text { NS }\end{array}$ & $\begin{array}{l}1.3 \\
1.4 \\
0.9 \\
\end{array}$ & $\begin{array}{l}0.6 / 3.1 \\
0.8 / 2.4 \\
0.4 / 2.7\end{array}$ & $\begin{array}{l}\text { NS } \\
\text { NS } \\
\text { NS }\end{array}$ \\
\hline \multirow[t]{3}{*}{ FENO, ppb } & $<20(-)$ & 1.7 & $0.8 / 3.3$ & $<0.05$ & 1.5 & $0.9 / 3.1$ & $<0.05$ \\
\hline & $20-35(+)$ & 1.3 & $0.3 / 3.4$ & NS & 0.9 & $0.4 / 2.9$ & NS \\
\hline & $>35(+)$ & 3.5 & $2.2 / 5.9$ & $<0.01$ & 2.9 & $1.4 / 4.9$ & NS \\
\hline CANO, ppb & $\begin{array}{l}>5(-) \\
\leq 5(+) \\
<300(+)\end{array}$ & $\begin{array}{l}1.9 \\
0.8 \\
0.9\end{array}$ & $\begin{array}{l}0.9 / 2.7 \\
0.2 / 1.7 \\
0.3 / 2.1 \\
\end{array}$ & $\begin{array}{l}<0.05 \\
\text { NS } \\
<0.05\end{array}$ & $\begin{array}{l}1.5 \\
0.7 \\
0.7\end{array}$ & $\begin{array}{l}0.8 / 2.6 \\
0.3 / 1.9 \\
0.2 / 1.8\end{array}$ & $\begin{array}{c}<0.05 \\
\text { NS } \\
\text { NS }\end{array}$ \\
\hline \multirow[t]{2}{*}{ 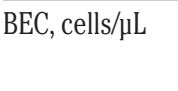 } & $300-600(+)$ & 1.6 & $0.8 / 3.5$ & NS & 1.4 & $0.7 / 2.9$ & NS \\
\hline & $\geq 600(-)$ & 1.3 & $0.6 / 2.3$ & NS & 1.2 & $0.5 / 2.1$ & NS \\
\hline
\end{tabular}

AAE, acute asthma exacerbation; SABA, short acting beta 2 agonist; FEV1, forced expiratory volume in $1 \mathrm{~s}$; FENO, fractional exhaled nitric oxide; CANO, concentration of nitric oxide in the gas phase of the alveolar; $F \mathrm{nNO}$, fractional concentration of nasally aspirated nitric oxide; ppb, part per billion; BEC, blood eosinophil count; NS, not significant difference; ${ }^{\circledR}$ measured at inclusion; ${ }^{\circledR}$ measured at 1 month; (-), risk of uncontrolled asthma; (+), positive agreement of controlled asthma.

In the management of asthma, especially in asthmatic children, the other important issue is how to predict the success of asthma management in order to recommend the appropriate asthma action plan. The results of this study showed that some clinical characteristics of subjects at inclusion had the significant predictive factors of asthma control at 3 months, evaluated by OR. These predictive factors included age of asthma onset, frequency of hospitalization in previous year, and asthma severity with airflow limitation (Table 4, Figure 4). For asthmatic children with low level of $F E N O$ at inclusion, they had a risk of uncontrolled asthma at 3 months whereas for whom with high level of FENO at inclusion had a good agreement for asthma control (Table 4, Figure 4). Interestingly, high level of $C A N O$ had a risk of uncontrolled asthma defined by GINA and ACT scores at 3 months (Table 4, Figure $4)$. These results suggest that the measurement of exhaled NO ( $F \mathrm{ENO}$ and $C \mathrm{ANO}$ ) might be used to predict the control of asthma in children who are naïve with ICS.

Until now, the studies on the role of CANO in asthmatic children are limited. The present study suggests a new approach in the control of asthma by measuring $C$ ANO concomitant with $F E N O$ in asthmatic children. However, the present study still has some limitations relating to the small number of study subjects and lack of long-term follow-up. In addition, the measurement of CANO needs the multiple flow device which is costlier and has not been extensively equipped in all asthma care centers. Thus, more studies on the role of exhaled NO as predictive biomarkers of asthma control in children should be undertaken to clarify its benefits and cost-effectiveness.

\section{Conclusions}

Children with asthma who are naïve with ICS usually have high levels of exhaled NO. High levels of FENO in asthmatic children might have a predictive value for controlled asthma. However, low levels of FENO and high levels of CANO can predict uncontrolled asthma in children. The measurement of exhaled $\mathrm{NO}$, especially CANO, is still a new area in the field of asthma management; therefore, more studies in this field should be done in the future.

\section{Acknowledgements}

The authors would like to thank all the Members of the Clinical Research Centers of Lam Dong Medical College for their contribution to this work. 


\begin{tabular}{|c|c|}
\hline \multicolumn{2}{|c|}{ List of abbreviations } \\
\hline AAE & acute asthma exacerbation; \\
\hline $\mathrm{ACT}$ & asthma control test; \\
\hline BEC & blood eosinophil count; \\
\hline BMI & body mass index; \\
\hline CANO & concentration of alveolar nitric oxide; \\
\hline FEF25-75 & forced expiratory flow at $25-75 \%$ of time; \\
\hline $\mathrm{FEV}_{1}$ & forced expiratory volume in 1 second; \\
\hline FENO & fractional exhaled nitric oxide; \\
\hline$F$ nNO & nasal nitric oxide; \\
\hline $\mathrm{FVC}$ & forced vital capacity; \\
\hline ICS & inhaled corticosteroid; \\
\hline LABA & long acting beta 2 agonist; \\
\hline LTRA & leukotriene receptor antagonist; \\
\hline NO & nitric oxide; \\
\hline PEFR & peak expiratory flow rate; \\
\hline $\mathrm{Ppb}$ & part per billion; \\
\hline SABA & short acting beta 2 agonist; \\
\hline SPT & skin prick test. \\
\hline
\end{tabular}

\section{References}

1. Global Initiative for Asthma. [Internet]. Archived reports. Accessed on: 29 April 2020. Available from: http:/ginasthma.org/archived-reports/

2. Centers for Disease Control and Prevention. [Internet]. Asthma in the US vital signs. 2011. Accessed on: 29 April 2020. Available

from: https://www.cdc.gov/vitalsigns/asthma/index.html

3. Akinbami LJ, Moorman JE, Bailey C, Zahran HS, King M, Johnson CA, Liu X. Trends in asthma prevalence, health care use, and mortality in the United States, 2001-2010. NCHS Data Brief 2012;1-8.

4. Toizumi M, Hashizume M, Nguyen HAT, Yasunami M, Kitamura N, Iwasaki C, Takegata M, Moriuchi H, Dang DA, Ariyoshi K, Yoshida LM. Asthma, rhinoconjunctivitis, eczema, and the association with perinatal anthropometric factors in Vietnamese children. Sci Rep 2019;9:2655.

5. Nga NN, Chai SK, Bihn TT, Redding G, Takaro T, Checkoway $\mathrm{H}$, et al. ISAAC-based asthma and atopic symptoms among Ha Noi school children. Pediatr Allergy Immunol 2003;14:272-9.

6. Cloutier MM, Schatz M, Castro M, Clark N, Kelly HW, Mangione-Smith R, et al. Asthma outcomes: composite scores of asthma control. J Allergy Clin Immunol 2012;129:S24-33.

7. Nguyen-Thi-Bich H, Duong-Thi-Ly H, Thom VT, et al. Study of the correlations between fractional exhaled 359 nitric oxide in exhaled breath and atopic status, blood eosinophils, FCER2 mutation, and asthma control in Vietnamese children. J Asthma Allergy 2016;9:163-70.

8. Dinh-Thi-Dieu H, Vo-Thi-Kim A, Tran-Van H, Tang-Thi-Thao T, Duong-Quy S. Study of the beneficial role of exhaled nitric oxide in combination with GINA guidelines for titration of inhaled corticosteroids in children with asthma. J Breath Res 2020. doi: 10.1088/1752-7163/ab6809.

9. Eguiluz-Gracia I, Tay TR, Hew M, Escribese MM, Barber D, O'Hehir RE, et al. Recent developments and highlights in biomarkers in allergic diseases and asthma. Allergy 2018;73: 2290-305.

10. Fitzpatrick AM. Biomarkers of asthma and allergic airway diseases. Ann Allergy Asthma Immunol 2015;115:335-40.

11. Hancox RJ, Pavord ID, Sears MR. Associations between blood eosinophils and decline in lung function among adults with and without asthma. Eur Respir J 2018;51:1702536.
12. Konradsen JR, Skantz E, Nordlund B, Lidegran M, James A, Ono J, et al. Predicting asthma morbidity in children using proposed markers of Th2-type inflammation. Pediatr Allergy Immunol 2015;26:772-9.

13. Sippel JM, Holden WE, Tilles SA, O'Hollaren M, Cook J, Thukkani N, et al. Exhaled nitric oxide levels correlate with measures of disease control in asthma. J Allergy Clin Immunol 2000;106:645-50.

14. Ozier A, Girodet PO, Bara I, Tunon de Lara J-M, Marthan R, Berger P. Control maintenance can be predicted by exhaled NO monitoring in asthmatic patients. Respir Med 2011;105:98996.

15. Michils A, Baldassarre S, Van Muylem A. Exhaled nitric oxide and asthma control: a longitudinal study in unselected patients. Eur Respir J 2008;31:539-46.

16. Wang Z, Pianosi P, Keogh K, Zaiem F, Alsawas M, Alahdab F, et al. The clinical utility of fractional exhaled nitric oxide (FeNO) in asthma management. Report No. 17(18)-EHC030EF. AHRQ Comparative Effectiveness Reviews. Rockville, MD: Agency for Healthcare Research and Quality (US); 2017.

17. Malinovschi A, Van Muylem A, Michiels S, Michils A. FeNO as a predictor of asthma control improvement after starting inhaled steroid treatment. Nitric Oxide 2014;40:110-6.

18. Duong-Quy S. Clinical utility of the exhaled nitric oxide (NO) measurement with portable devices in the management of allergic airway inflammation and asthma. J Asthma Allergy 2019;12:331-41.

19. National Institute for Health and Care Excellence (NICE). [Internet]. Asthma: diagnosis, monitoring and chronic asthma management. Accessed on: 28 April 2020. Available from: https://www.nice.org.uk/guidance/ng80/chapter/Recommenda tions\#diagnosing-asthma-in-young-children

20. Scichilone N, Battaglia S, Taormina S, Modica V, Pozzecco E, Bellia V. Alveolar nitric oxide and asthma 352 control in mild untreated asthma. J Allergy Clin Immunol 2013;131:1513-7.

21. Berry M, Hargadon B, Morgan A, Shelley M, Richter J, Shaw $\mathrm{D}$, et al. Alveolar nitric oxide in adults with asthma: Evidence of distal lung inflammation in 355 refractory asthma. Eur Respir J 2005;25:986-91.

22. Sardón O, Corcuera P, Aldasoro A, Korta J, Mintegui J, Emparanza JI, Pérez-Yarza EG. Alveolar nitric oxide and its role in pediatric asthma control assessment. BMC Pulm Med 2014; 14:126.

23. Nguyen-Thi-Bich H, Duong-Thi-Ly H, Thom VT, Pham-ThiHong N, Doan Dinh L, Le-Thi-Minh H, et al. Study of the correlations between fractional exhaled 359 nitric oxide in exhaled breath and atopic status, blood eosinophils, FCER2 mutation, and asthma control in Vietnamese children. J Asthma Allergy 2016;9:163-70.

24. Condorelli P, Shin HW, Aledia AS, Silkoff PE, George SC. A simple technique to characterize proximal and peripheral nitric oxide exchange using constant flow exhalations and an axial diffusion model. J Appl Physiol 2007;102:417-25.

25. Dweik RA, Boggs PB, Erzurum SC, Irvin CG, Leigh MW, Lundberg JO, et al. An official ATS clinical practice guideline: interpretation of exhaled nitric oxide levels (FENO) for clinical applications. Am J Respir Crit Care Med 2011;184:602-15.

26. Bobrowska-Korzeniowska M, Stelmach I, Brzozowska A, Jerzyńska J, Mitał M, Stelmach W. The effect of passive smoking on exhaled nitric oxide in asthmatic children. Nitric Oxide 2019;86:48-53.

27. Duong-Quy S, Hua-Huy T, Mai-Huu-Thanh B, Doan-ThiQuynh N, Le-Quang K, Nguyen-Van H, et al. Early detection of smoking related chronic obstructive pulmonary disease in Vietnam. Rev Mal Respir 2009;26:267-74.

28. Akinbami LJ, Kit BK, Simon AE. Impact of environmental 
Multidisciplinary Respiratory Medicine 2020; 15:656 - X. Ngo-Minh et al.

tobacco smoke on children with asthma, United States, 20032010. Acad Pediatr 2013;13:508-16.

29. Wang Z, May SM, Charoenlap S, Pyle R, Ott NL, Mohammed $\mathrm{K}$, Joshi AY. Effects of secondhand smoke exposure on asthma morbidity and health care utilization in children: a systematic review and metaanalysis. Ann Allergy Asthma Immunol 2015; 115:396-401.

30. Beck-Ripp J, Griese M, Arenz S, Köring C, Pasqualoni B, Bufler P. Changes of exhaled nitric oxide during steroid treatment of childhood asthma. Eur Respir J 2002;19:1015-9.

31. Smith AD, Cowan JO, Brassett KP, Herbison GP, Taylor DR. Use of exhaled nitric oxide measurements to guide treatment in chronic asthma. N Engl J Med 2005;352:2163-73.

32. Puckett JL, Taylor RW, Leu SY, Guijon OL, Aledia AS, Galant
SP, George SC. Clinical patterns in asthma based on proximal and distal airway nitric oxide categories. Respir Res 2010; 11:47.

33. Zinellu E, Piras B, Ruzittu GGM, Fois SS, Fois AG, Pirina P. Recent advances in inflammation and treatment of small airways in asthma. Int J Mol Sci 2019;20:377.

34. 32. Paredi P, Kharitonov SA, Meah S, Barnes PJ, Usmani OS. A novel approach to partition central and peripheral airway nitric oxide. Chest 2014;145:113-9.

35. Dinh-Xuan AT, Annesi-Maesano I, Berger P, Chambellan A, Chanez $\mathrm{P}$, Chinet $\mathrm{T}$, et al. Contribution of exhaled nitric oxide measurement in airway inflammation assessment in asthma. A position paper from the French Speaking Respiratory Society. Rev Mal Respir 2015;32:193-215.

Received for publication: 10 April 2020. Accepted for publication: 4 May 2020.

This work is licensed under a Creative Commons Attribution-NonCommercial 4.0 International License (CC BY-NC 4.0).

CCopyright: the Author(s), 2020

Licensee PAGEPress, Italy

Multidisciplinary Respiratory Medicine 2020; 15:656

doi:10.4081/mrm.2020.656 